\title{
Heavy Metal Contents in Topsoil of Selected Public Primary Schools Playground in Benin Metropolis, Nigeria
}

\author{
*BIOSE, E; AMAECHI, CF; NWAEMENE, C
}

Department of Environmental Management and Toxicology, Faculty of Life Sciences, University of Benin, PMB 1154, Benin City

*Corresponding Author Email: ekene.biose@uniben.edu

\begin{abstract}
This study was carried out to determine some physicochemical properties and heavy metals level in primary school playground located in Benin City, Southern Nigeria using standard methods. A total of 10 topsoil samples were collected from five primary school playgrounds from different locations in Benin metropolis, Southern Nigeria in February, 2017. The mean levels of $\mathrm{pH}$ and $\mathrm{EC}$ ranged from 5.53 to 7.02 and $200.05-410.00 \mu \mathrm{S} / \mathrm{cm}$ respectively. The mean concentrations for heavy metals ranged from $337.15 \pm 64.28$ and $464.10 \pm 19.37$ for $\mathrm{Fe}, 23.40 \pm 7.50$ and $29.70 \pm 4.81$ for $\mathrm{Mn}, 45.95 \pm 8.70$ and $67.95 \pm 4.74$ for $\mathrm{Zn}, 8.48 \pm 1.61$ and $12.90 \pm 3.82$ for $\mathrm{Cu}, 5.10 \pm 2.33$ and $7.41 \pm 1.54$ for $\mathrm{Cd}, 4.42 \pm 2.02$ and $8.39 \pm 7.09$ for $\mathrm{Cr}, 6.17 \pm 2.82$ and $13.82 \pm 6.76$ for $\mathrm{Pb}, 0.99 \pm 0.09$ and $3.24 \pm 3.73$ for $\mathrm{Ni}$ respectively. Heavy metal concentrations were in the following order. In Ogiegbaen, Eresoyen and Ekosodin Primary schools (PS) playground, the order was $\mathrm{Fe}>\mathrm{Zn}>\mathrm{Mn}>\mathrm{Cu}>\mathrm{Pb}>\mathrm{Cd}>\mathrm{Cr}>\mathrm{Ni}$ while the order in Agbado PS and Olua PS were $\mathrm{Fe}>\mathrm{Zn}>\mathrm{Mn}>\mathrm{Cu}>\mathrm{Pb}>$ $\mathrm{Cr}>\mathrm{Cd}>\mathrm{Ni}$ and $\mathrm{Fe}>\mathrm{Zn}>\mathrm{Mn}>\mathrm{Pb}>\mathrm{Cu}>\mathrm{Cd}>\mathrm{Cr}>\mathrm{Ni}$ respectively. Enrichment factor (EF), Contamination factor (CF) and Geoaccumulation index (Igeo) were used to evaluate the pollution status of the soil.
\end{abstract}

\section{DOI: https://dx.doi.org/10.4314/jasem.v25i2.6}

Copyright: Copyright $\odot 2021$ Biose et al. This is an open access article distributed under the Creative Commons Attribution License (CCL), which permits unrestricted use, distribution, and reproduction in any medium, provided the original work is properly cited.

Dates: Received: 12 December 2020; Revised: 26 January 2021; Accepted: 12 February 2021

Keywords: Topsoil, Playground, Heavy metals, Assessment Indices

Soil parent material imparts a natural range of concentration of metals including heavy metals in soil. The soil of the urban environment receives higher load of metals than that of their rural environment from traffic and industries and, since metals are rather immobile once they reach the soil system, accumulation occurs resulting in levels that can be harmful to humans including children, upon repeated exposure (Thornton, 1991). As population increases in urban areas, good quality of soil is essential to the health of the urban inhabitants (Li et al., 2001). Children in particular are more susceptible to the adverse health effects of soil metal pollution especially from the heavy metal due to their small body size, developing nervous system and high absorption rate (Li et al., 2001). Maddaloni et al., 1998 reported that ingested $\mathrm{Pb}$ that is absorbed in an adult's body is typically less than $5 \%$, in contrast to that of children which is as high as $50 \%$ due to their less developed gastrointestinal tract. In recent years, environmental contaminants including heavy metals such as arsenic, lead and mercury, which can be quite harmful if ingested have become increasingly common in our surroundings (Miguel et al., 2007). Heavy metal which are among the more serious pollutants in the human environment because of their toxicity, persistence and bioaccumulation characteristics (Annao et al., 2008), have been implicated in the upsurge of liver and kidney diseases, pains in bones, mutagenic, carcinogenic and teratogenic effects (Alloway and Ayres, 2002; Orisakwe et al., 2012, Jaradat and Monani, 1999), neurological disorders, especially in the fetus and in children which can lead to behavioral changes and impaired performance in IQ tests (Alloway, 1995). Children have the propensity to explore the world through their mouth and are therefore exposed to heavy metals contamination via absorption through skin, food, ingestion of treated materials such as wood, contaminated soil and inhaling of contaminated air (Evelyn et al., 2015). Children also ingest more soil than adults via the handto-mouth pathway and when they put dirty hands and objects into their mouths (Lanphear and Roughmann, 1997; Schutz et al., 1997). Soil ingestion has been recognized as an equally important exposure route of contaminants to humans as water and food ingestion (McKone and Daniels, 1991), especially for children up to the age of six due to their hand-to-mouth behaviour (Mielke and Reagan, 1998). Soil ingestion and soil metal exposure are also dependent on the time spent outside and the location of the outdoor playing facilities. While some children in urban areas have 
private gardens for outdoor activities, others are confined to public playgrounds. In Benin City where the present study was carried out, children within the age bracket of 2-5 attend some type of daycare/nursery education center, while nearly all 6-year olds attend elementary classes at either private or public primary schools were they spend part of their outdoor time in the playground and in the process are exposed to biological, physical and chemical hazardous contents of the soil. Some of the educational centers in Benin City are situated close to high traffic area for sole purpose of easy accessibility thus the rate of accumulation of heavy metal in the soil via vehicle exhaust; industrial and other commercial activities are likely to be high. Few studies have investigated children's playgrounds in Nigeria (Evelyn et al., 2015). No report currently exist on the status of contamination of public schools playgrounds by heavy metals in Benin City in spite of the fact that these playgrounds present themselves as appropriate targets for the accumulation of heavy metals because of the bare nature of the soil. Comprehensive information about these metals is of primary importance to detect unusual concentrations, predict outbreaks of possible health problems and formulate preventive measures to curb possible health defects. The objective of this study is therefore to determine some physicochemical properties and heavy metals level in primary school playground in Benin City, Southern Nigeria.

\section{MATERIALS AND METHODS}

Study Location Area: This research was conducted in Benin City, Edo State (6 $\left.200^{\prime} 00 \mathrm{~N}, 5^{\circ} 37^{\prime} 20 \mathrm{E}\right)$ (Fig. 1). Criteria such as population activity, traffic density and road sections were considered while selecting the sample sites. The soil samples were collected and their geographic coordinates recorded with a global positioning system (GPS) at five different sites within
Benin metropolis. Site 1: Eresoyen Primary School, Oluku, Ovia North East (6 $6^{\circ} 26^{\prime} 55^{\prime \prime}$ N $\quad 5^{\circ} \quad 35^{\prime}$ 50' E), Site 2: Ekosodin Primary School, Ekosodin Ovia North East (6 $6^{\circ} 24^{\prime} 31^{\prime \prime}$ N $5^{\circ} 37^{\prime} 36^{\prime}$ ' E), Site 3: Olua Primary School, Egor (6 $6^{\circ} 21^{\prime} 43^{\prime}$ ' N $5^{\circ} 37^{\prime}$ 5', E), Site 4: Agbado Primary School, Oredo (6 $6^{\circ} 20^{\prime} 22^{\prime}$ ', N 5' 37' 49',E,) Site 5: Ogiegbaen Primary School, Ikpoba Okha (6 $6^{\circ} 20^{\prime} 39^{\prime}$ ' N5 $5^{\circ} 41^{\prime} 27^{\prime}$ ' E).

Micro climate of the study area: According to UNDP, (2006), the rain pattern is characteristics of the rainforest zone with mean rainfall of $3000 \mathrm{~mm}$ (Agbaire and Emoyan, 2012) which is distributed between April to October, followed by marked dry season (of up to four months) November to February. The ranges of maximum and minimum temperatures are high and fairly constant throughout the year while the average monthly temperature for the warmest months ranged from $28^{\circ} \mathrm{C}$ to $33^{\circ} \mathrm{C}$ and the average monthly temperature for the coolest month ranges from $22^{\circ} \mathrm{C}$ to $26^{\circ} \mathrm{C}$.

Sample Collection: Soil samplings were collected at random in the primary school playgrounds. Three discrete soil samples were collected from each of the selected point and pooled to form a composite sample. Two replicate samples were collected from each primary school playground, making it a total of 10 samples. The number of samples collected at each point was based on the circumstances that existed at the point of collection including the spots were the children played during breaks in the playground. About $100 \mathrm{~g}$ of topsoil was collected with a hand trowel into a polyethene bag and labeled before taken to the laboratory (Robertson, 2003). This method was used because it is easier and more readily available. Samples were collected once in the month of February, 2017.

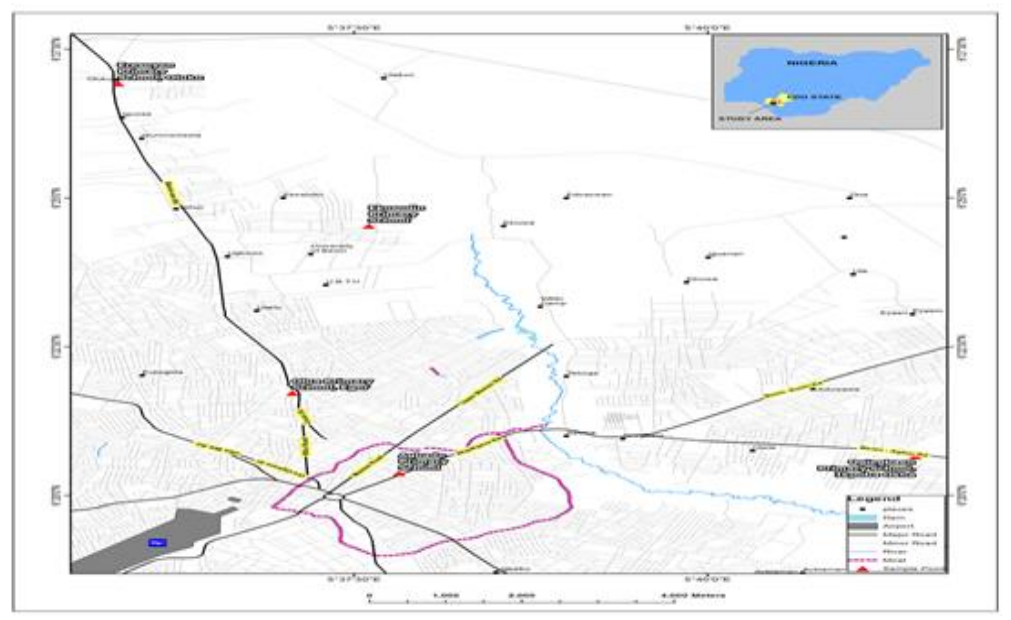

Fig 1: Map of Benin City showing the sampling sites

BIOSE, E; AMAECHI, CF; NWAEMENE, C 
Soil Sample preparation: The soil samples collected were air-dried at room temperature $25^{\circ} \mathrm{C}-27^{\circ} \mathrm{C}$ for two to three days, thereafter samples were crushed and sieved through a $2 \mathrm{~mm}$ sieve and packed in well labelled sample cups for laboratory analysis. The samples were analysed for the following chemical properties using defined procedures. Soil $\mathrm{pH}$ was measured and Electrical conductivity were determined according to the method of Davey and Conyers (1988) and APHA (2005) respectively. Necessary precautionary quality assurance measures were observed to prevent sample contamination.

Heavy metal analysis: Heavy metals were analysed at the Ecotoxicology laboratory, University of Benin, Benin City. Sample digestion and the determination of the heavy metal concentration were carried out according to the method of the Association of Analytical Chemists, (AOAC, 2000). After the digested samples have been cooled, the mixture was diluted with distilled water to $100 \mathrm{ml}$ and subsequently analysed by using Atomic Absorption Spectrophotometer (AAS Bulk Scientific 210 VGP) to determine the concentrations of Copper $(\mathrm{Cu})$, Manganese $(\mathrm{Mn})$, Lead $(\mathrm{Pb})$, cadmium $(\mathrm{Cd})$, Zinc $(\mathrm{Zn})$, Iron $(\mathrm{Fe})$, Chromium $(\mathrm{Cr})$ and Nickel (Ni).

Statistical analysis: All the data obtained were subjected to descriptive analysis, (measure of central tendency and dispersion) to characterize the samples. The comparison of each study area was carried out to test for significant differences in the chemical conditions using parametric analysis of variance (ANOVA). If significant value $(\mathrm{P}<0.05)$ were obtained in the ANOVA, Duncan multiple range (DMR) test was performed to determine the location of significant difference. All data analyses including Enrichment Factor, Contamination Factor (CF), Pollution Load Index (PLI), and Geo-accumulation Index (Igeo), were done using SPSS 20.00 version and Microsoft excel (2003) windows application.

Assessment of soil contamination: The: Evaluation of Data - Risk Assessment: Enrichment Factor (EF)

The formula for enrichment factor (Levy et al., 1992) is stated below

$$
\mathrm{EF}=\frac{\left(\frac{\mathrm{X}}{\mathrm{Fe}}\right)_{\text {soil }}}{\left(\frac{\mathrm{X}}{\mathrm{Fe}}\right)_{\text {background }}}
$$

Where $\mathrm{EF}=$ enrichment factor, $(\mathrm{X} / \mathrm{Fe})_{\text {soil }}$ is the ratio of heavy metal $(\mathrm{X})$ to $\mathrm{Fe}$ in the soil samples. According to Sutherland (2000), five categories are generally recognized on the basis of enrichment factor $(\mathrm{EF})$.
When EF $<2$ depletion of mineral enrichment or no enrichment; $2 \leq \mathrm{EF}<5$ moderate enrichment; $5 \leq \mathrm{EF}<20$ significant enrichment; $20 \leq \mathrm{EF}<40$ very high enrichment; EF $>40$ extremely high enrichment

Pollution Load Index (PLI) and Contamination Factor $(C F)$ : The contamination factor $(\mathrm{CF})$ and pollution load index (PLI) are expressed as follows:

$$
\mathrm{CF}=\frac{\mathrm{C}_{\text {metal concentration }}}{\mathrm{C}_{\text {background concentration of the metal }}}
$$

It is assessed as the ratio obtained by dividing the concentration of each metal in the soil by baseline or background value (concentration in uncontaminated soil):

$$
C F_{\text {metal }}=\frac{C_{\text {metal }}}{C_{\text {background }}}
$$

According to Hakanson (1980), CF values were interpreted as follows: If $\mathrm{CF}<1$ : it means that low contamination exists. If $1<\mathrm{CF}>3$ : it means that moderate contamination exists. If $3<\mathrm{CF}<6$ : it means that considerable contamination exists. If $\mathrm{CF}>6$ : it means that very high contamination exists. While PLI can be expressed as

$$
\begin{aligned}
& \text { PLI of a study area } \\
& =\sqrt[n]{C_{f}^{i} 1 \times C_{f}^{i} 2 \times C_{f}^{i} 3 \times C_{f}^{i} \ldots \times C_{f}^{i} n}
\end{aligned}
$$

For assessing the level of heavy metal pollution this empirical index provides a simple, comparative means. When PLI $>1$, it means that a pollution exists; otherwise, If PLI $<1$, there is no metal pollution.

The geo-accumulation index (Igeo) is expressed by Muller, (1969) as:

$$
I_{\text {geo }}=\frac{\log ^{2}\left(C_{n}\right)}{1.5\left(B_{n}\right)}
$$

Where $C_{n}$ is the metals concentration in soil samples and $B_{n}$ is the geochemical background concentration of the metal (n). Factor 1.5 is the background matrix correction factor due to lithospheric effects. The Igeo index consists of seven classes ranging from practically unpolluted to extremely polluted.

Class 0 (practically unpolluted): Igeo $\leq 0$; Class 1 (unpolluted to moderately polluted): $0<$ Igeo $<1$; Class 2(moderately polluted): $\quad 1<$ Igeo $<2$; Class 3 (moderatelyto heavily polluted): $2<$ Igeo $<3$; Class 4 (heavily polluted): $3<$ Igeo $<4$; Class 5 (heavily to extremely polluted): $4<$ Igeo $<5$; Class 6 (extremely polluted):5>Igeo 


\section{RESULT AND DISCUSSION}

Physical and chemical characteristics of Soil: The results of the chemical characteristics including $\mathrm{pH}$, electrical conductivity and the heavy metals concentrations of soil samples obtained from the selected primary schools (PS) playgrounds within Benin Metropolis (in mean and standard deviation for each parameter) are given in Tables 1. Continual urbanization and industrialization induces heavy metals emissions into our environment which may greatly affect human health. Pollution of surface soil with toxic heavy metals has become a major global concern due to growing health risks to the public (Ahmed and Ishiga, 2006; Khashman, 2007). The pH of a soil is one of the most frequently measured parameters due to the importance of $\mathrm{pH}$ in regulating numerous processes. The $\mathrm{pH}$ gives an indication of the acidity or alkalinity and this makes it valuable for soil characterization. Many chemical reactions are $\mathrm{pH}$ dependent and knowledge of the $\mathrm{pH}$ can be useful in predicting the extent and speed of chemical reactions (Radojevic and Bashkin, 1999). The $\mathrm{pH}$ value obtained at Olua primary school was alkaline in nature having a $\mathrm{pH}$ of 7.02 while other primary school playgrounds were slightly acidic with a range of 5.53 at Ekosodin PS to 6.89 at Agbado PS. The slightly acidic nature of the soils could affect the solubility and greater retention of metals in the soils (Mirjana et al., 2009). The $\mathrm{pH}$ of the soil samples to some extent maintained clear significant difference between Olua PS and other primary school playgrounds in this study. Acidic soil was obtained from Ekosodin Primary School. No strong correlations were found between heavy metal contents as similar observation was opined by Ljung $e t$ al., (2006). Electrical conductivity measurements are not as widely applied in soil analysis compared to $\mathrm{pH}$ (Radojevic and Bashkin, 1999). Soil electrical conductivity can be used as a measure of total soluble ions in a given soil sample. The electrical conductivity of the soil across the various primary schools were relatively similar, thus no significant difference ( $p>0.05$ ) was obtained. The electrical conductivity showed significant and positive correlation with zinc, thus increase in the level of zinc would in turn influence the electrical conductivity positively.

Table 1: Summary of the spatial variations in the parameters characterized in the top soil samples from the selected primary school playgrounds

\begin{tabular}{|c|c|c|c|c|c|c|}
\hline \multirow[b]{2}{*}{ Parameters } & \multicolumn{5}{|c|}{ Primary Schools } & \multirow[b]{2}{*}{ p-value } \\
\hline & $\begin{array}{l}\text { Ogiegbaen } \\
\bar{X} \pm \text { SD }\end{array}$ & $\begin{array}{l}\text { Agbado } \\
\bar{X} \pm \text { SD }\end{array}$ & $\begin{array}{l}\text { Olua } \\
\bar{X} \pm \text { SD }\end{array}$ & $\begin{array}{l}\text { Eresoyen } \\
\bar{x} \pm \text { SD }\end{array}$ & $\begin{array}{l}\text { Ekosodin } \\
\bar{x} \pm \text { SD }\end{array}$ & \\
\hline pH & $5.72 \pm 0.01^{\mathrm{c}}$ & $6.89 \pm 0.06^{\mathrm{a}}$ & $7.02 \pm 0.13^{\mathrm{a}}$ & $6.37 \pm 0.33^{b}$ & $5.53 \pm 0.16^{\mathrm{c}}$ & $\mathrm{p}<0.01$ \\
\hline $\mathrm{EC}(\boldsymbol{\mu} \mathrm{S} / \mathrm{cm})$ & $206.50 \pm 19.09$ & $410.00 \pm 0.71$ & $292.50 \pm 153.44$ & $234.50 \pm 106.77$ & $200.50 \pm 13.44$ & $\mathrm{p}>0.05$ \\
\hline Fe (mg/kg) & $391.60 \pm 6.65$ & $464.10 \pm 19.37$ & $347.40 \pm 79.48$ & $408.25 \pm 19.59$ & $337.15 \pm 64.28$ & $\mathrm{p}>0.05$ \\
\hline Mn (mg/kg) & $27.55 \pm 0.64$ & $29.70 \pm 4.81$ & $23.40 \pm 7.50$ & $29.20 \pm 1.84$ & $28.35 \pm 11.81$ & $\mathrm{p}>0.05$ \\
\hline Zn (mg/kg) & $58.80 \pm 5.80$ & $67.95 \pm 4.74$ & $60.75 \pm 6.72$ & $56.35 \pm 17.04$ & $45.95 \pm 8.70$ & $\mathrm{p}>0.05$ \\
\hline Cu (mg/kg) & $12.90 \pm 3.82$ & $12.50 \pm 0.85$ & $11.50 \pm 1.70$ & $9.74 \pm 2.21$ & $8.48 \pm 1.61$ & $\mathrm{p}>0.05$ \\
\hline Cd (mg/kg) & $7.41 \pm 1.54$ & $6.66 \pm 3.91$ & $9.31 \pm 3.95$ & $5.10 \pm 2.33$ & $5.82 \pm 0.13$ & $\mathrm{p}>0.05$ \\
\hline $\mathrm{Cr}(\mathrm{mg} / \mathrm{kg})$ & $6.43 \pm 1.34$ & $8.39 \pm 7.09$ & $7.79 \pm 3.69$ & $4.42 \pm 2.02$ & $5.05 \pm 0.11$ & $\mathrm{p}>0.05$ \\
\hline Pb (mg/kg) & $9.28 \pm 2.30$ & $10.01 \pm 7.49$ & $13.82 \pm 6.76$ & $6.17 \pm 2.82$ & $7.04 \pm 0.16$ & $\mathrm{p}>0.05$ \\
\hline $\mathrm{Ni}(\mathrm{mg} / \mathrm{kg})$ & $1.76 \pm 0.37$ & $0.99 \pm 0.09$ & $3.24 \pm 3.73$ & $1.21 \pm 0.55$ & $1.38 \pm 0.03$ & $\mathrm{p}>0.05$ \\
\hline
\end{tabular}

Table 2 shows the enrichment factor (EF) in the Study area

\begin{tabular}{llllll}
\hline Heavy & \multicolumn{5}{c}{ Primary Schools } \\
\cline { 2 - 6 } Metals & Ogiegbaen & Agbado & Olua & Eresoyen & Ekosodin \\
\hline Mn & 0.61 & 0.56 & 0.59 & 0.62 & 0.73 \\
$\mathbf{Z n}$ & 0.84 & 0.82 & 0.98 & 0.77 & 0.76 \\
$\mathbf{C u}$ & 0.87 & 0.71 & 0.87 & 0.63 & 0.66 \\
$\mathbf{C d}$ & 5.31 & 4.02 & 7.52 & 3.50 & 4.84 \\
$\mathbf{C r}$ & 3.74 & 4.12 & 5.11 & 2.47 & 3.41 \\
$\mathbf{P b}$ & 5.84 & 5.31 & 9.81 & 3.72 & 5.15 \\
$\mathbf{N i}$ & 2.28 & 1.08 & 4.72 & 1.50 & 2.07 \\
\hline
\end{tabular}

Table 3: The concentration factor and the pollution load index of the Study area

\begin{tabular}{l|llllllll|l}
\hline \multirow{2}{*}{$\begin{array}{l}\text { Primary } \\
\text { School }\end{array}$} & Fe & $\mathrm{Mn}$ & $\mathrm{Zn}$ & $\mathrm{Cu}$ & $\mathrm{Cd}$ & $\mathrm{Cr}$ & $\mathrm{Pb}$ & $\mathrm{Ni}$ & PLI \\
\hline Ogiegbaen & 4.29 & 2.63 & 3.60 & 3.73 & 22.80 & 16.06 & 25.07 & 9.78 & 7.79 \\
Agbado & 5.09 & 2.84 & 4.16 & 3.62 & 20.48 & 20.96 & 27.04 & 5.47 & 7.81 \\
Olua & 3.81 & 2.23 & 3.72 & 3.33 & 28.63 & 19.48 & 37.35 & 17.97 & 8.90 \\
Eresoyen & 4.48 & 2.79 & 3.45 & 2.82 & 15.68 & 11.04 & 16.66 & 6.72 & 6.26 \\
Ekosodin & 3.70 & 2.71 & 2.81 & 2.45 & 17.91 & 12.61 & 19.03 & 7.67 & 6.23 \\
\hline
\end{tabular}

Results from this study which was restricted to topsoil of selected primary school playground in Benin metropolis shows that the playground are polluted with $\mathrm{Cd}, \mathrm{Cr}, \mathrm{Pb}$ and $\mathrm{Ni}$ and other metals which can arise 
from atmospheric and anthropogenic deposition. It is a common practice to compare mean concentrations of heavy metals in urban soils from different urban settings. Putting this into consideration, the concentrations of all the heavy metals analyzed in this study showed no significant difference ( $p>0.05)$ across the primary schools playgrounds. The result of this study showed that Fe was the most abundant heavy metal in soil samples obtained across the various schools. This observation contradicted the record of Verla et al. (2015a) which had zinc as the dominant heavy metal in playgrounds of public schools within Owerri Metropolis, Imo State. This difference can be attributed to spatial and geological compositional differences in the soil. Generally, Ni was the least concentrated of all the heavy metals analyzed in this study. In ranking of the heavy metals in order of decreasing concentration, slight differences were observed. In Ogiegbaen, Eresoyen and Ekosodin primary schools, the order was $\mathrm{Fe}>\mathrm{Zn}>\mathrm{Mn}>\mathrm{Cu}>\mathrm{Pb}>$ $\mathrm{Cd}>\mathrm{Cr}>\mathrm{Ni}$ while the order in Agbado and Olua primary schools were $\mathrm{Fe}>\mathrm{Zn}>\mathrm{Mn}>\mathrm{Cu}>\mathrm{Pb}>\mathrm{Cr}>\mathrm{Cd}>$ $\mathrm{Ni}$ and $\mathrm{Fe}>\mathrm{Zn}>\mathrm{Mn}>\mathrm{Pb}>\mathrm{Cu}>\mathrm{Cd}>\mathrm{Cr}>\mathrm{Ni}$ respectively. $\mathrm{Fe}$ is found everywhere in the environment i.e. from debris, waste from automobiles, household waste, brake wheels etc. are built up in the environment and was seen to be the most abundant heavy metal recorded (Kanu et al., 2015). The concentration of Fe at Ogiegbaen PS, Agbado PS, Olua PS, Eresoyen PS and Ekosodin PS are 391.60, 464.10, $347.40,408.25$ and $337.15(\mathrm{mg} / \mathrm{kg})$ respectively. Lower concentrations were recorded Ekosodin PS followed by Olua PS. High level of variability was recorded at Olua PS and this can be attributed to the large landmass which happened to be the highest among the various primary schools investigated. This factor increased the distance for composite sample collection thus the reduction in sample homogeneity. The highest concentrations of $\mathrm{Fe}$ was recoded at Agbado PS. Statistical analysis showed no significant difference $(\mathrm{P}>0.05)$ on the concentration of $\mathrm{Fe}$ in the soil when compared to other primary schools playground soils. The concentrations of $\mathrm{Fe}$ found in the various soil samples were low when compared to the value of $22,991 \mathrm{mg} / \mathrm{kg}$ and $8522 \mathrm{mg} / \mathrm{kg}$ obtained by $\mathrm{Ng}$ et al. (2003) and Miguel et al. (2007) in playground in Hong Kong and Madrid, Spain respectively.

Table 4: Igeo of heavy metal contamination in the study areas

\begin{tabular}{llllll}
\hline \multicolumn{5}{c}{ Heavy } & \multicolumn{5}{c}{ Primary Schools } \\
\cline { 2 - 6 } Metals & Ogiegbaen & Agbado & Olua & Eresoyen & Ekosodin \\
\hline Fe & 1.52 & 1.76 & 1.34 & 1.58 & 1.30 \\
Mn & 0.81 & 0.92 & 0.58 & 0.89 & 0.85 \\
Zn & 1.26 & 1.47 & 1.31 & 1.20 & 0.91 \\
$\mathbf{C u}$ & 1.32 & 1.27 & 1.15 & 0.91 & 0.71 \\
$\mathbf{C d}$ & 3.93 & 3.77 & 4.25 & 3.39 & 3.58 \\
$\mathbf{C r}$ & 3.42 & 3.80 & 3.70 & 2.88 & 3.07 \\
$\mathbf{P b}$ & 4.06 & 4.17 & 4.64 & 3.47 & 3.67 \\
$\mathbf{N i}$ & 2.70 & 1.87 & 3.58 & 2.16 & 2.35 \\
\hline
\end{tabular}

Table 5: Summary of the Correlation Table for Test of Relationship among the Parameters Characterized in the Top Soil Samples from the

\begin{tabular}{|c|c|c|c|c|c|c|c|c|c|c|}
\hline & $\mathrm{pH}$ & $\mathrm{EC}$ & $\mathrm{Fe}$ & $\mathrm{Mn}$ & $\mathrm{Zn}$ & $\mathrm{Cu}$ & $\mathrm{Cd}$ & $\mathrm{Cr}$ & $\mathrm{Pb}$ & $\mathrm{Ni}$ \\
\hline $\mathrm{pH}$ & 1.000 & & & & & & & & & \\
\hline $\mathrm{EC}$ & 0.526 & 1.000 & & & & & & & & \\
\hline $\mathrm{Fe}$ & 0.290 & 0.214 & 1.000 & & & & & & & \\
\hline $\mathrm{Mn}$ & -0.175 & -0.114 & 0.659 & 1.000 & & & & & & \\
\hline $\mathrm{Zn}$ & 0.410 & 0.716 & 0.512 & 0.102 & 1.000 & & & & & \\
\hline $\mathrm{Cu}$ & 0.192 & 0.485 & 0.311 & -0.018 & 0.828 & 1.000 & & & & \\
\hline $\mathrm{Cd}$ & 0.336 & -0.347 & 0.109 & -0.169 & 0.015 & 0.197 & 1.000 & & & \\
\hline $\mathrm{Cr}$ & 0.365 & -0.103 & 0.368 & -0.135 & 0.231 & 0.281 & 0.870 & 1.000 & & \\
\hline $\mathrm{Pb}$ & 0.445 & -0.204 & 0.190 & -0.171 & 0.141 & 0.235 & 0.981 & 0.916 & 1.000 & \\
\hline $\mathrm{Ni}$ & 0.272 & -0.477 & 0.081 & 0.115 & -0.196 & -0.106 & 0.772 & 0.461 & 0.734 & 1.000 \\
\hline
\end{tabular}

The concentration of Mn recorded at Ogiegbaen PS, Agbado PS, Olua PS, Eresoyen PS and Ekosodin PS are $27.55,29.70,23.40,29.20$ and $28.35(\mathrm{mg} / \mathrm{kg})$ respectively. $\mathrm{Mn}$ is a micro nutrient required by plants and man and it is found in the organic matter in the soil (Orhue and Usi, 2015). Lower concentrations were recorded at Olua PS while Agbado PS had the highest concentration. However the concentrations of $\mathrm{Mn}$ recorded in this study were high but showed no significant difference $(\mathrm{P}>0.05)$ on the concentration of $\mathrm{Mn}$ in the soil when compared to other primary schools playground soils. Other researchers have reported similar concentration of $\mathrm{Mn}$ and attributed the level of Mn to anthropogenic sources especially when the primary schools were located along traffic zones and other industrial activities which could have increased the level in the playground soils (Kanu et al., 2015) 
The concentration of $\mathrm{Zn}$ recorded at Ogiegbaen PS, Agbado PS, Olua PS, Eresoyen PS and Ekosodin PS are $58.80,67.95,60.75,56.35$ and $45.95(\mathrm{mg} / \mathrm{kg})$ respectively. The highest concentration was recorded at Agbado PS while the lowest concentration was recorded at Ekosodin PS. Statistical analysis showed no significant difference $(\mathrm{P}>0.05)$ on the concentration of $\mathrm{Zn}$ in the soil when compared to other primary schools playground soils. EL- GAmmal et al., (2005) and Kamani et al., (2015) reported high levels of zinc in soils close to traffic areas and attributed it to wear and tear of automobile tire. However, the prevalence of $\mathrm{Zn}$, though the least toxic among all heavy metals (Ladipo and Doherty, 2011) is indicative of the significance of zinc in our ecosystem (Olukanni and Adeoye, 2012). The health implications of elevated levels of zinc $\left(\mathrm{Zn}^{2+}\right)$ are severe vomiting, diarrhoea, bloody urine, liver and kidney failure and anaemia (Fosmire, 1990). The concentration of $\mathrm{Cu}$ recorded at Ogiegbaen PS, Agbado PS, Olua PS, Eresoyen PS and Ekosodin PS are 12.90, 12.50, 11.50, 9.74 and 8.48 $(\mathrm{mg} / \mathrm{kg})$ respectively. Statistical analysis showed no significant difference $(\mathrm{P}>0.05)$ on the concentration of $\mathrm{Cu}$ in the soil when compared to other primary schools playground soils. The lowest concentration of $\mathrm{Cu}$ was recorded at Ekosodin PS while the highest concentration was recorded at Ogiegbaen PS. Excess intake of soluble copper compounds can result in the accumulation of $\mathrm{Cu}$ in the liver and may lead to an alteration of liver function to handle copper and to arrange for its use and elimination from the body. Consequently copper can be released into the blood stream producing haemolysis (El-Gammal et al., 2005). Overall, the average concentrations of $\mathrm{Mn}, \mathrm{Zn}$ and $\mathrm{Cu}$ obtained in the soil samples from the various primary schools playgrounds were low when compared with the values of $75.79 \mathrm{mg} / \mathrm{kg}, 124.98$ $\mathrm{mg} / \mathrm{kg}$ and $32.91 \mathrm{mg} / \mathrm{kg}$ respectively obtained by Verla et al. (2015a) in playgrounds of public schools within Owerri Metropolis, Imo State, Nigeria. The concentration of $\mathrm{Cd}$ and $\mathrm{Cr}$ recorded at Ogiegbaen PS, Agbado PS, Olua PS, Eresoyen PS and Ekosodin PS are $7.41,6.66,9.31,5.10$ and $5.82(\mathrm{mg} / \mathrm{kg})$ for $\mathrm{Cd}$ and $6.43,8.39,7.79,4.42$ and $5.05(\mathrm{mg} / \mathrm{kg})$ for $\mathrm{Cr}$ respectively. The highest concentration of $\mathrm{Cd}$ and $\mathrm{Cr}$ were recorded at Olua PS and Agbado PS while the lowest concentrations of $\mathrm{Cd}$ and $\mathrm{Cr}$ were recorded at Eresoyen PS. Statistical analysis showed no significant difference $(\mathrm{P}>0.05)$ on the concentration of $\mathrm{Cd}$ and $\mathrm{Cr}$ in the soil when compared to other primary schools playground soils. It was observed that the concentration of $\mathrm{Cd}$ and $\mathrm{Cr}$ in Eresoyen PS was lower than that of Ekosodin PS. Ekosodin PS is located at Ekosodin village and it is the only primary school that is not along the road in this study. However, the high concentrations of $\mathrm{Cd}$ and $\mathrm{Cr}$ recorded in Ekosodin PS can be attributed to the fact that Ekosodin PS is sitting on a sloppy landmass according to the geography of the area. Therefore, the high concentration recorded can be attributed to runoffs of soils deposits which end up towards Ekosodin PS playground. Cadmium can also be emitted into the environment from agricultural discharge, zinc, lead or copper smelters and through incineration of municipal waste materials (ATSDR, 1997). Long term exposure to cadmium is associated with renal dysfunction, anaemia, bone marrow disorder, cancer, bronchitis, liver and brain disorders (Dara, 2000; Koji et al., 2004). The concentration of $\mathrm{Pb}$ and $\mathrm{Ni}$ recorded at Ogiegbaen PS, Agbado PS, Olua PS, Eresoyen PS and Ekosodin PS are 9.28, 10.01, 13.83, 6.17 and $7.04(\mathrm{mg} / \mathrm{kg})$ for $\mathrm{Pb}$ and $1.76,0.99$, $3.24,1.21$ and $1.38(\mathrm{mg} / \mathrm{kg})$ for Ni respectively. The highest concentration of $\mathrm{Pb}$ and $\mathrm{Ni}$ were recorded at Olua PS for both heavy metals while the lowest concentrations of $\mathrm{Pb}$ and $\mathrm{Ni}$ were recorded at Eresoyen PS and Agbado PS respectively. Statistical analysis showed no significant difference $(\mathrm{P}>0.05)$ on the concentration of $\mathrm{Pb}$ and $\mathrm{Ni}$ in the soil when compared to other primary schools playground soils. It has been reported that roadside soils near traffic are polluted by $\mathrm{Pb}$ and other metals (Wong and Mak, 1997). Conversely, in this study, the concentration of $\mathrm{Pb}$ recorded at Ekosodin PS which is located far away from traffic was higher than values recorded at Eresoyen PS which is located along Benin-Lagos high way. However, this can be attributed to the high runoff of soil particles that end up in Ekosodin PS playground. Lead poising $\left(\mathrm{Pb}^{2+}\right)$ has been found to be the major cause of haemoglobin synthesis, dysfunction in the kidney, hypertension, impairment of central nervous system, damage to gastro-intestinal system, mental retardation in children, abnormalities in fertility and pregnancy, cardiovascular systems and other respiratory problems in adults (Olade, 1987; Dara, 2000; Ferner, 2001; Ikenaka et al., 2010). It has been reported that children are more susceptible to $\mathrm{Pb}$ toxicity because intestinal absorption of $\mathrm{Pb}$ is five times greater in children than in adults (Ikenaka et al., 2010). $\mathrm{Cd}, \mathrm{Cr}, \mathrm{Pb}$ and $\mathrm{Ni}$ recorded low levels of variations; however the levels would continue to increase due to increasing anthropogenic or natural inputs. The soil samples obtained from Olua and Agbado primary playground recorded the highest levels of $\mathrm{Cd}, \mathrm{Cr}, \mathrm{Pb}$ and $\mathrm{Ni}$ as this can be attributed to high vehicle usage of the roads positioned close to these schools and often time high traffic congestion along those roads. Thus $\mathrm{Cd}, \mathrm{Cr}, \mathrm{Pb}$ and $\mathrm{Ni}$ input can be associated to input from the vehicle exhaust and other industrial and commercial activities. It was observed that the concentration of $\mathrm{Mn}, \mathrm{Cd}, \mathrm{Cr}, \mathrm{Pb}$ and $\mathrm{Ni}$ was high in Ekosodin PS due to runoff of soil particles which can lead to bioaccumulation of metals in soils 
of Ekosodin PS playgrounds. Generally, the values obtained for the selected primary school playground in Benin metropolis clearly indicated that these playgrounds have been polluted by anthropogenic emissions except for Ekosodin primary school that has been attributed to other sources of metal pollution. Various studies have shown that heavy metals such as $\mathrm{Cd}, \mathrm{Cr}, \mathrm{Pb}$ and $\mathrm{Ni}$ amongst others are responsible for certain diseases that have lethal effects on man and animals, and due to their accumulation and long-time retention by plants and animals, these metals are very dangerous (Popescu, 2011) in Olukanni and Adeoye, (2012).

Correlation matrixes for chemical properties and heavy metals in soils of selected primary school playgrounds: The correlation between the concentrations of some geochemical parameters can establish influencing factors and indicate potential sources of pollution (Robertson et al., 2003; Crosby, 2012) in Otari and Dabiri, (2015). The result of the correlation analysis between the parameters showed that there was a positive correlation between the elements with regards to their sources and origin. Considering the sample size, the critical level of correlation coefficient is $0.632 . \mathrm{pH}$ recorded no significant relationship with any of the parameters characterized in this study while EC showed a significant and positive correlation with $\mathrm{Zn}(\mathrm{r}=0.717)$. $\mathrm{Fe}$ recorded significant and positive correlation with $\mathrm{Mn}(\mathrm{r}=0.659)$ while $\mathrm{Zn}$ showed the same pattern of relationship with $\mathrm{Cu} \quad(\mathrm{r}=0.828) . \quad \mathrm{Cd}$ recorded significant and positive correlations with $\mathrm{Cr}(\mathrm{r}=0.870)$ and $\mathrm{Pb}(\mathrm{r}=0.981)$ while $\mathrm{Pb}$ showed similar pattern of relations with $\mathrm{Cr}(\mathrm{r}=0.916)$ and $\mathrm{Ni}(\mathrm{r}=0.734)$. These positive correlations indicates $\mathrm{Fe}, \mathrm{Mn}, \mathrm{Cu}, \mathrm{Cd}, \mathrm{Cr}, \mathrm{Pb}$ and $\mathrm{Ni}$ may have originated from common sources, preferably from different industrial and commercial activities as well as contribution from auto-exhaust.

Enrichment Factor: The findings from this study reveal high levels of $\mathrm{Cd}, \mathrm{Cr}, \mathrm{Pb}$ and $\mathrm{Ni}$ contamination in the soil which is in line with the findings of Zhang and Liu, (2002), Salah et al., (2012) who reported that both lithogenic and anthropogenic sources may have a significant role in the enrichment of $\mathrm{Zn}, \mathrm{Pb}$, and $\mathrm{Cd}$ and attributed these sources to urbanization, industrialization and runoff (Kanu et al., 2015; Kamani et al., 2015). The findings revealed high levels of $\mathrm{Cd}, \mathrm{Cr}$ and $\mathrm{Pb}$ contamination in the soil. Thus, it is possible that these metals are increasing due to anthropogenic activities of man while stating the obvious of incomplete combustion of vehicular emissions which can increase the level of heavy metals in theses soils.
Contamination Factor $(C F)$ : The contamination factor indicated a considerable contamination of $\mathrm{Fe}$ in all the study areas as $\mathrm{CF}$ for $\mathrm{Fe}$ is $3<\mathrm{CF}<6$. There is a moderate contamination of $\mathrm{Mn}$ in all the study area as $\mathrm{CF}$ for $\mathrm{Mn}$ is $1<\mathrm{CF}>3$. There is a moderate contamination of $\mathrm{Zn}$ at Ekosodin PS while other study areas recorded a consideration contamination of $\mathrm{Zn}$. There was a moderate contamination of $\mathrm{Cu}$ at Eresoyen PS and Ekosodin PS while other PS recorded considerable contamination in soils of their playgrounds. There was a very high contamination of $\mathrm{Cd}, \mathrm{Cr}$ and $\mathrm{Pb}(\mathrm{CF} \geq 6)$ in all the study areas while to Ni recorded a considerable contamination $(3<\mathrm{CF}<6)$ at Agbado PS. Ogiegbaen PS, Olua PS, Eresoyen PS and Ekosodin PS had a very high contamination of metals as $\mathrm{CF}$ value was $\mathrm{CF} \geq 6$ in the primary school playgrounds respectively. Nwaogu et al., (2014) and Sripathy et al., (2015) reported similar result and attribute the contamination level in soils to anthropogenic sources that normally go on soil through human activities.

Pollution Load Index (PLI): In this study, PLI value across all the study areas indicates that all the sampled areas were all polluted (PLI > 1) by heavy metals. This is in line with various studies carried out in traffic areas which showed that the soil samples have been contaminated by the anthropogenic activities in study locations (Olukanni and Adebiyi, 2012; Otari and Dabiri, 2015) respectively.

Geoaccumulation Index (Igeo): All the soils of the study area fell within the seven classes of risk assessment based on Muller's interpretation. In relation to $\mathrm{Fe}$, the soil samples obtained from the study areas were moderately polluted as Igeo values were $(1<$ Igeo<2). In relation to $\mathrm{Mn}$, the soil samples obtained from all the study areas was practically unpolluted (Igeo $\leq 0$ ). In relation to $\mathrm{Zn}$, the soil samples obtained from Ogiegbaen PS, Agbado PS, Olua PS and Eresoyen PS were moderately polluted as Igeo values were $(1<$ Igeo $<2)$ while the soil sample obtained from Ekosodin PS was practically unpolluted (Igeo $\leq 0)$. The soil samples obtained for $\mathrm{Cu}$ from Ogiegbaen PS, Agbado PS and Olua PS were moderately polluted as Igeo values were $(1<$ Igeo $<2)$ while the soil sample obtained from Eresoyen PS and Ekosodin PS were practically unpolluted (Igeo $\leq 0$ ). In relation to $\mathrm{Cd}$, the soil samples obtained from Ogiegbaen PS, Agbado PS, Eresoyen PS and Ekosodin PS were heavily polluted $(3<$ Igeo $<4)$, while the soil sample obtained from Olua PS was heavily to extremely polluted $(4<$ Igeo $<5)$ with $\mathrm{Cd}$. In relation to $\mathrm{Cr}$, the soil samples obtained from Ogiegbaen PS, Agbado PS, Olua PS and Ekosodin PS were heavily polluted $(3<$ Igeo<4), while the soil sample obtained 
from Eresoyen PS was moderately to heavily polluted $(2<$ Igeo $<3)$. In relation to $\mathrm{Pb}$, the soil samples obtained from Ogiegbaen PS, Agbado PS and Olua PS were heavily to extremely polluted $(4<$ Igeo $<5)$, while the soil sample obtained from Eresoyen PS and Ekosodin PS were heavily polluted $(3<$ Igeo<4). In relation to $\mathrm{Ni}$, the soil samples obtained from Agbado PS was moderately polluted $(1<$ Igeo $<2)$, the soil samples obtained from Ogiegbaen PS, Eresoyen PS and Ekosodin PS were moderately to heavily polluted $(2<$ Igeo $<3)$, while the soil sample obtained from Olua PS was heavily polluted $(3<$ Igeo<4) with Ni. Similar findings were reported by Otari and Dabiri (2015) as soils were significantly contaminated by $\mathrm{Cr}$ and $\mathrm{Ni}$ with anthropogenic origin from mining activities. Similar Igeo value was reported by Zakir et al., (2015) which further is in agreement with the report of Howari et al., (2004), who opined that soils collected at industrial and commercial areas close to traffic locations were moderately contaminated with $\mathrm{Cd}, \mathrm{Pb}$ and $\mathrm{Ni}$.

Conclusion: Heavy metals concentrations were low when compared with the values obtained elsewhere in the world, however, they can accumulate to constitute health hazards. The present data can help in the assessment and establishment of future monitoring programs focusing on metal contamination in the environment. It is also needful to constantly monitor concentrations in order to detect any possible chance of risk to full exposure.

\section{REFERENCES}

Agbaire, PO; Emoyan, OO (2012). Bioaccumulation of heavy metals by earthworm (Lumbricus terrestris) and associated soils in domestic dumpsite in Abraka, Delta State, Nigeria. Int. J. Plant Anim. Environ. Sci. Vol 2(3): 210-217

Agency for Toxic Substances and Disease Registry (ATSDR) (1997). Toxicological Profile for Cadmium. Draft for Public Comment. Public Health Service, U.S. Department of Health and Human Services, Atlanta, GA.

Ahmed, F; Ishiga, H (2006). Trace metal concentration in street dusts of Dhaka City, Bangladesh. Atmos Environ 40: 3835-3844.

Alloway, BJ; Ayres, DC (2002). Chemical principles of environmental pollution, 2nd edition, Blackie Academic and professional, London, pp 157-245

Alloway, BJ (1995). Heavy Metal in solid. Blackie and Sons, Glasgo, pp 96-153
American Public Health Association APHA, (2005). Standard Methods for the Examination of Water and Wastewater Analysis. American Water Works Associationand Water Environment Federation. $6^{\text {th }}$ Edition, Washington DC.

Annao, WL; Nurdans, DAK; Cheung, CC; d-Mingh, W (2008). Heavy Metals Concentrations of Surface Dust from Waste Recycling and Its Human Health Implications in Southeast China, Environ. Sc. and Tech., 42(7), 2671-2680

Association of Analytical chemistry (A.O.A.C). (2000). Official methods of Analysis of A.O.A.C.., INTERNATIONAL $17^{\mathrm{TH}}$ Edition. Vol. II. Gaithen burf, M.D, USA, Official method. 920-957

Crosby, CJ (2012). Application of mineral magnetic measurements as a pollution proxy for urban road deposited sediment. PhD Thesis, University of Wolverhampton, $353 \mathrm{pp}$.

Dara, SS (2000). A Textbook of environmental Chemistry and pollution control (pp. 39-42). New Delhi: S. Chand and Company Ltd.

Davey, BG; Conyers, MK (1988). Determining the $\mathrm{pH}$ of acid soils. Soil Sci, 146: 141-150

El-Gammal, M.I; Shakour, AA; Ibrahim, MS; ElHenawy, RS (2005). "Air pollution and suspended particulate matter in atmosphere of Damietta cityEgypt". J. Egypt. Ger. Soc.; 47(A): 251-281.

Evelyn, NV; Spiff, AI; Horsfall, M. Jnr (2015). A preliminary survey of Heavy metals concentrations in Children playground within Owerri Metropolis, Imo State, Nigeria. Res $J$ Chem Sci, 5(11), 1-8

Ferner, DJ (2001). Toxicity, Heavy Metals. Med., 2(5): 1.

Fosmire, GS (1990). Zinc Toxicity. Am. J. Clin. Nutr., 51(2): 225-227.

Hakanson, L (1980). An ecological risk index for aquatic pollution control. A sedimentological approach. Water Res 14(8): 975-1001

Howari, FM; Abu-Rukah, H; Goodell, PC (2004). Heavy metal pollution of soils along North ShunaAqaba Highway, Jordan. Int J. Environ and Pollut, 22(5): 597-607 
Ikenaka, Y; Nakayama, SMM; Muzandu, K; Choongo, K; Teraoka, H; Mizuno, N; Ishizuka, M (2010). Heavy metal contamination of soil and sediment in Zambia. Afr J Environ Sci Technol Vol. 4(11): $1-11$

Jaradat, QM; Monani, KA (1999). Contamination of roadside soil, plant and air with heavy metal in Jordan, a comparative study, Turkish .J. Chem, 23, 209-220.

Kamani, H; Ashrafi, SD; Isazadeh, S; Jaafari, J; Hoseini, M; Mostafapour, FK; Bazrafshan, E; Nazmara, S; Mahvi, AH (2015). Heavy Metal Contamination in Street Dusts with Various Land Uses in Zahedan, Iran. Bull Environ Contam Toxicol, 186(8): 5059-5067

Kanu, MO; Meludu, OC; Oniku, SA (2015). Evaluation of Heavy Metal Contents in Road Dust of Jalingo, Taraba State, Nigeria. Jordan J Earth Environ Sci. 7(1): 65-70

Khashman, OA (2007). Determination of metal accumulation in deposited street dusts in Amman, Jordan. Environ Geochem Health 29 (1) 1-10.

Koji, N; Kobayashi, E; Okubo, Y; Suwazono, Y (2004). Environmental cadmium exposure, adverse effects, and preventative measures in Japan. Biometals 17(5): 581-587.

Ladipo MK; Doherty VF (2011). Heavy metal levels in vegetables from selected markets in Lagos, Nigeria. Afri J Food Sci Technol. 2(1): 18-21.

Lanphear, BP; Roughmann, KJ (1997). Pathways of lead exposure in urban children. Environ Res, 74: $67-73$.

Levy, DB; Barbarick, KA; Siemer, EG; Sommers, LE (1992). Distribution and partitioning of trace metals in contaminated soils near Leadville, Colorado. J Environl Qty. 21(2): 185-195

Li, X; Poon, CS; Liu, PS (2001). Heavy metal contamination of urban soils and street dusts in Hong Kong. Appl Geochem 16:1361-8.

Ljung, K; Selinus, O; Otabbong, E (2006). Metals in soils of children's urban environments in the small northern European city of Uppsala. Sci. Total Environ 366: 749- 759

Maddaloni, M; LoIacono, N; Manton, W; Blum, C; Drexler, J; Graziano, J (1998) Bioavailability of soil-borne lead in adults by isotope dilution. Environ Health Perspect. 106:1589- 94.

McKone, TE; Daniels, JI (1991). Estimating human exposure through multiple pathways from air, water and soil. Regul Toxicol Pharmacol. 13: 36 $-61$

Mielke, HW; Reagan, PL (1998). Soil is an important pathway of human lead exposure. Environ Health Perspect, 106:217- 29.

Miguel, ED; Iribarren, I; Chacon, E; Ordonez, A; Charlesworth, A (2007). Risk-based evaluation of the exposure of children to trace elements in playgrounds in Madrid (Spain). Chemosphere, 66, 505-513.

Mirjana, DM; Marija, MV; Dušan, GA; Suzana, ID; Đorđe, MJ; Milan, NM; Mirjana, ĐR (2009). Heavy metals concentration in soils from parks and green areas in Belgrade. J. Serb. Chem. Soc. 74 (6): 697-706

Muller, G (1969). Index of geo-accumulation in sediments of the Rhine River. Geo. J. 2(3):108118.

Ng, SL; Chan, LS; Lam, KC; Chan, WK (2003). Heavy metal contents and magnetic properties of playground dust in Hong Kong. Environ Monit. Assess. 89, 221-232.

Nwaogu, LA; Ujowundu, CO; Iheme, CI; Ezejiofor, TNI; Belonwu, DC (2014). Effects of Sublethal Concentration of heavy metalcontamination on soil Physicochemical Properties, catalase and Dehydrogenase Activities. Int J Biochem Res Rev 4(2): 141-149

Olade MA. (1987). "Lead Mercury, Cadmium and Arsenic in the environment". Edited by T.C. Hutchinson and K.M. Meema. John Wiley and Sons Ltd. Chapter 20, pp. 335-341.

Olukani, DO; Adeoye, DO (2012). Heavy metal concentration in road side soils from selected locations in the Lagos Metropolis, Nigeria. Int $J$ Res Eng Technol 2(10): 1743-1752

Olukanni, DO; Adebiyi, SA (2012). Assessment of vehicular pollution of road side soils in Ota Metropolis, Ogun State, Nigeria. Int J Civil Environ Eng, 12(4): 40-46. 
Orhue, ER; Usi, CJ (2015). Changes in Some Physical and Chemical Properties of Soils as Influenced by Okpella Cement Factory. J. Int. Environ App Sci. 10(2): 178-183

Orisakwe, OE; Nduka, JK; Amadi, CN; Dike, DO; Bede, O (2012) Heavy metals health risk assessment for population via consumption of food crops and fruits in Owerri, South Eastern, Nigeria, Chem. Cent. Journ., 6, 77

Otari, M; Dabiri, R (2015). Geochemical and Environmental Assessment of heavy metals in soils and sediments of Forumad Chromite mine, NE of Iran. J Mining Environ. 6(2): 251-261

Popescu CG (2011). Relation between vehicle traffic and heavy metals from the particulate matters. Romanian Reports in Physics. 63(2): 471-482.

Radojevic, M; Bashkin, VN (1999). Practical environmental analysis. Royal school of chemistry, Thomas Graham house, science park Cambridge, UK. 645pp

Robertson, DJ; Taylor, KG; Hoon, SR (2003). Geochemical and mineral magnetic characterization of urban sediments particulates, Manchester, UK. App Geochem 18: 269-282

Salah, EAM; Zaidan, TA; Al-Rawi, AS (2012). Assessment of heavy metals pollution in the sediments of Euphrates River, Iraq. J Wat Res Protect. 4: 1009-1023

Schutz, A; Barregard, L; Sallsten, G; Wilske, J; Manay, N; Pereira, L (1997). Blood lead in
Uruguayan children and possible sources of exposure. Environ Res, 74:17 - 23.

Sripathy, L; Pratima-Rao, NM; Ajay, KSY; Jagadisha, ND; Sharada, KR (2015). Heavy Metal Contamination of Soil due to Vehicular Traffic: A Case Study Accross Nelamangala-Dabaspet Segment of National Highway No. 4. Rasayan J. Chem. 8(2): 232-236

Thornton I (1991) Metal contamination in urban areas. In: Bullock P, editor. Soils in the urban environment. Cambridge University Press. pp. 47-75.

UNDP, (2006). Nigeria Delta Human Development Report. P. 229

Verla, EN; Verla, AW; Ugwulor, L (2015 a). Seasonal variation of heavy metals in playgrounds of public schools within Owerri Metropolis, Imo State, Nigeria. Int L Chem, Phy Astron, 50: 61-70

Zakir, HM; Sumi, SA; Sharmin, S; Mohiuddin, KM; Kaysar, S (2015). Heavy Metal Contamination in Surface Soils of Some Industrial Areas of Gazipur, Bangladesh. Journal of Chemical, Biological and Physical Sciences. An International Peer Review E-3 J Sci. Vol 5 (2): 2191-2206.

Zhang, J; Liu, CL (2002). Riverine composition and estuarine geochemistry of particulate metals in China-weathering features, anthropogenic impact and chemical fluxes. Estuar. Coast. Shelf. S. 54: 1051-1070 